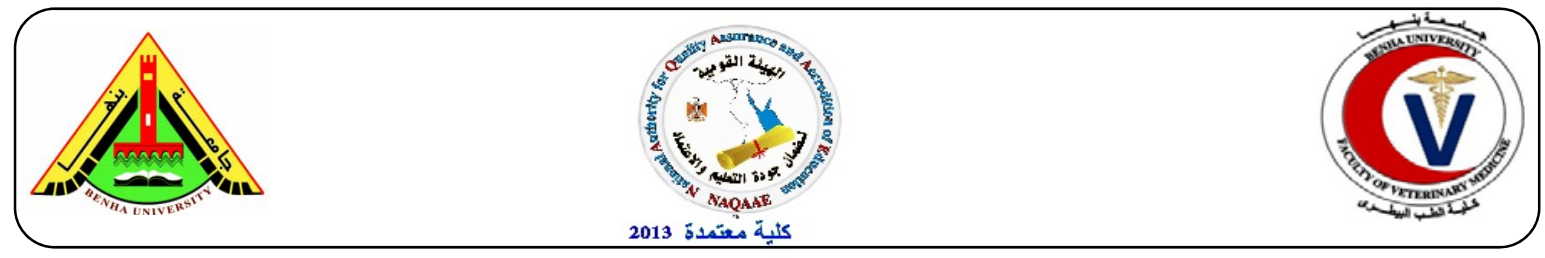

\title{
Biochemical Effect of Olive Leaves on Experimentally Induced Cardiac Stress in Rats
}

\author{
Abd El-Maksoud H.A., Raafat R. Mohammed and Nagih M. Hassan \\ Biochemistry Dep. Fac. Vet. Med.Benha University.
}

\section{A B S T R A C T}

The present study was designed to evaluate the Protective effects of Olive laeves in Chronic myocardial necrosis induced experimentally in rats by subcutaneously injection with Isoproternol at adose of (5 $\mathrm{mg} / \mathrm{kg} \mathrm{b.wt} \mathrm{in} 1 \mathrm{ml}$ saline, s.c) weekly for 8 weeks . Blood samples were collected three times at the $3 \mathrm{rd}$, 6th and one week after the 8th injection and 10 rats were sacrificed from each group at the time of blood samples. The present data showed that the experimental induction of cardiac necrosis accompanied by increases in the in mean values of serum Creatine kinase (CK)., Creatine kinase MB (CK-MB)., Lactate dehydrogenase (LDH)., Aspartate amino transferase (AST), glucose, erythrocytes Glucose 6 phosphate dehydrogenase. (G-6-PD), Potassium (K)., Phosphorus (P)., Total protein (T.P.), and albumin and cardiac muscles L- malondialdehyde (L-MDA).and significant decreases in heart tissues Superoxide Dismutase (SOD). and Catalase (CAT) and serum Calcium (Ca)., Sodium (Na).in the ISO group while the treatement with olive leaves retain these changes nearly to normal values

Keywords: Creatine kinase, Catalase, Olive Leaves, Cardiac Stress

(http://www.bvmj.bu.edu.eg)

(BVMJ-29(2): 208-217, 2015)

\section{INTRUDUCTION}

$\mathrm{T}$ The olive tree (Olea europaea L), family: Oleaceae, and in particular, its leaves have been used for the treatment of wounds, fever, diabetes, gout, atherosclerosis and hypertension since ancient times, further more studies show a direct beneficial role for olive oil in improving plasma lipids in the treatment of metabolic syndrome (Alonso et al., 2006). Oleuropein, the active principle of olives, is a phenolic compound which has been shown to possess diverse healing properties for its vasodilatory, hypotensive (Khayyal et al., 2002), anti-rheumatic, antiatherogenic (Visioli and Galli, 2002) and antipyretic (Visioli et al., 1995) effects. Many of these pharmacologic features of oleuropein are due to its potent antioxidant action (Visioli et al., 2002). The term "myocardial infarction" is a sudden deprivation of circulating blood. More rarely infarction may result from prolonged vasospasm, inadequate myocardial blood flow (e.g., hypotension) excessive embolic occlusion vacuities, aortic root or coronary artery dissection, or aortitis (El izabeth et al., 2012). Myocardial infarction (MI) is one of the main causes of death from cardiovascular disease. MI is defined as an acute condition of necrosis of the myocardium that occurs as a result of imbalance between coronary blood supply and myocardial demand (Mudagal et al., 2011). MI increases the generation of reactive oxygen species in ischemic tissue, bringing about oxidative damage of membrane lipids, proteins, carbohydrates, and DNA and brings changes in the mechanical, electrical, structural and biochemical properties of the heart (Wang et al., 2009) thus a great deal of research is focused on the role of antioxidants in the prevention of many human diseases, particularily atherosclerosis, congestive 
heart failure and myocardial ischemia reperfusion injury restaraion of the flow of blood to a previously ischemic tissue or organ (Patel et al., 2010 and Tinkel et al., 2012). The present study was designed to evaluate the protective effect and treatment effect of Olive laeves administration on cardiac necrosis markers, some electrolytes and cardiac tissue antioxidants in myocardial necrosis induced experimentally in rats.

\section{MATERIALS and METHODS}

\subsection{Experimental animals:}

A total number of 120 male albino rats of (12-16 weeks) old, weighting 180-220 g was used in the experimental investigation of this study.

\subsection{Preparation of Isoproternol injection:}

Twenty $\mathrm{mg}$ of the isoproternol powder (obtained from sigma chemical company) in $1 \mathrm{ml}$ saline solution $/ \mathrm{kg}$ b.wt.

\subsection{Induction of myocardial necrosis:}

The prepaired solution is injected subcutaneously at a dose of $(20 \mathrm{mg} / \mathrm{kg}$ b.wt in $1 \mathrm{ml}$ saline, s.c) twice for two consecutive days at an interval of 24 hours to induce acute myocardial necrosis, and at a dose of $5 \mathrm{mg} / \mathrm{kg}$ b.wt weekly for induction of chronic myocardial necrosis (Saravanan and Prakash, 2004)

\subsection{Medicinal plant:}

Olive leaves powder: after gathering the olive leaves from some regions of Borg ElArab (Egypt), the leaves were washed by distilled water and dried. The leaves were then powdered and passed through mesh to increase their contact with powdered ration.

\subsection{Experimental design:}

Rats were allocated into 4 groups as follow: First group (Group I) Control group (CN): Consists of 30 rats fed on the tabulated ordinary rat ration through the whole time of experiment. Second group (Group II) Isoproternol group (ISO): (Chronic Heart necrotic group as positive control) composed of 30 rats were fed the tabulated ordinary rat ration and injected subcutaneously with isoproternol at adose of $(5 \mathrm{mg} / \mathrm{kg}$ b.wt in $1 \mathrm{ml}$ saline, s.c) weekly for 8 weeks. Third Group (Group III) Treated group: Composed of 30 rats kept on powdered olive leaves through the whole time of experiment and injected subcutaneously with isoproternol at adose of $(5 \mathrm{mg} / \mathrm{kg}$ b.wt in $1 \mathrm{ml}$ saline, s.c) week;y for 8 weeks. Fourth group (Group IV) Olive leaves group: Consists of 30 rats reared on powdered olive leaves through the whole time of experiment.

\subsection{Blood samples:}

Blood samples were collected three times at the $3 \mathrm{rd}$, 6th and one week after the 8th injection and 10 rats were sacrificed from each group at the time of blood samples which were divided into 2 parts: A - Serum samples separated by centrifugation at 3000 r.p.m. for 15 minutes. After blood clotting. B- Heparinized tubes for whole blood were collected for the determination of Glucose 6 phosphate dehydrogenase.

\subsection{Preparation of heart tissue:}

Heart samples were collected with blood samples. Imediately after killing the animals by decapitation, the heart was removed by dissection. Heart tissue was washed with a PBS (phosphate buffered saline) solution, $\mathrm{pH} 7.4$ containing 0.016 $\mathrm{mg} / \mathrm{ml}$ heparin to remove any red blood cells and clots. About $0.05 \mathrm{~g}$ of heart was

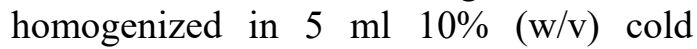
phosphate buffer saline (PBS) (i.e., $50 \mathrm{Mm}$ potassium phosphate, $\mathrm{pH} 7.5,0.1 \mathrm{Mm}$ EDTA) per gram tissue, using tissue homogenizer. Centrifuge at 4,000 r.p.m for 20 minutes at $4^{\circ} \mathrm{C}$, the resulting supernatant was assayed for Catalase activity according to (Sinha, 1972). SOD activity according to (Nishikimi et al., 1972). c- (L-MDA) concentration at liver, kidney and brain according to (Ohkawa et al., 1979). Determination of serum Creatine kinase (CK) (Bauer, 1982), Creatine kinase-MB (CK-MB) (Urdal and Lanndaas1979), 
lactate dehydrogenase (LDH) (Scientific Committee 1982), Aspartate Amino Transferase (AST) (Reitman and Frankel 1957), Albumin (Douma et al., 1971), Glucose (Trinder1969). Calcium (McLean and Hastings 1935), Sodium, (Bauer,1982), Potassium (Berry et al.1989) and Phosphorus (Gamst and Try 1980).

\section{RESULTS}

The present data in table (1) showed in comparison with the mean values of the control group that, the mean value of serum CK , CK-MB , LDH , AST , glucose, erythrocytes G-6-PD , potassium, phosphorous, total protein , and albumin increased highly significant $(p<0.01)$ in the ISO group at the $3^{\text {rd }}$ and $6^{\text {th }}$ week of injection which became very highly significant increase $(p<0.001)$ at the $9^{\text {th }}$ week injection while in the treated group the increase was significt $(\mathrm{p}<0.05)$ at the $3^{\text {rd }}$ and $9^{\text {th }}$ week of injection while at the $6^{\text {th }}$ week it was highly significant $(p<0.01)$. The olive leaves group which acts as a positive control was almost similar to the control or negative control group with no significant increase in $\mathrm{CK}$ at any period. Whereas The illustrated showed in comparison with the mean values of the control group that the mean value of serum calcium, sodium had a significant decrease $(p<0.05)$ at the $3^{\text {rd }}, 6^{\text {th }}$ and $9^{\text {th }}$ week in the ISO groups. The treated group instead showed no significant decrease at any period. Also, the olive leaves group showed no significant decrease at any period similar to the control group. The mean value of heart tissues SOD, CAT had a significant decrease $(p<0.05)$ in the ISO administrated group all over the period of experiment. The treated group instead showed no significant decrease at any period. in comparison with the mean values of the control group Also, the olive leaves group showed no significant increase $t$ any period similar to the control group. Whereas the mean values of cardiac muscles (L-MDA) had a highly significant increase $(p<0.01)$ at all periods in the ISO injected groups. The treated group instead showed no significant increase at any period. Also, the olive leaves group showed no significant increase at any period similar to the control group.

Table (1): The mean values of serum CK, CK - MB, LDH and AST in control, cardiac infarction and olive leaves treated groups

\begin{tabular}{llccc}
\hline \multirow{2}{*}{ Test } & Groups & \multicolumn{3}{c}{ Periods } \\
& & $3^{\text {rd }}$ week & $6^{\text {th }}$ week & $9^{\text {th }}$ week \\
\hline \multirow{4}{*}{ CK } & Control (-ve) & $149.30 \pm 10.40$ & $160.81 \pm 11.79$ & $169.31 \pm 11.18$ \\
& ISO & $611.70 \pm 18.83^{* *}$ & $792.83 \pm 20.15^{* *}$ & $1128.78 \pm 22.15^{* * *}$ \\
& Treated & $482.81 \pm 23.81^{*}$ & $509.75 \pm 20.11^{* *}$ & $458.01 \pm 17.31^{*}$ \\
& Olive leaves Control (+ve) & $145.83 \pm 16.51^{*}$ & $152.85 \pm 8.01 *$ & $160.15 \pm 10.31^{*}$ \\
& Control (-ve) & $216.60 \pm 7.10$ & $223.70 \pm 8.99$ & $232.81 \pm 9.15$ \\
CK-MB & ISO & $489.81 \pm 14.12^{*}$ & $677.83 \pm 20.83^{* *}$ & $808.79 \pm 23.58^{* *}$ \\
& Treated & $431.38 \pm 12.11^{*}$ & $410.58 \pm 16.03 *$ & $321.83 \pm 11.83$ \\
& Olive leaves Control (+ve) & $218.15 \pm 6.66$ & $229.83 \pm 10.51$ & $231.75 \pm 8.87$ \\
& Control (-ve) & $498.81 \pm 16.15$ & $483 \pm 15.39$ & $519.83 \pm 11.75$ \\
LDH & ISO & $821.70 \pm 11.53 *$ & $772.83 \pm 19.77^{*}$ & $2243.39 \pm 51.32^{* * *}$ \\
& Treated & $501.83 \pm 8.31$ & $500.70 \pm 8.83$ & $511.81 \pm 10.51$ \\
& Olive leaves Control (+ve) & $107.83 \pm 6.67$ & $115.11 \pm 8.11$ & $109.82 \pm 7.30$ \\
& Control (-ve) & $291.81 \pm 7.51 * *$ & $315.11 \pm 9.70 * *$ & $378.81 \pm 10.57 * *$ \\
AST & ISO & $242.56 \pm 8.31 * *$ & $151.36 \pm 8.89$ & $131.75 \pm 7.77$ \\
& Treated & $109.81 \pm 4.62$ & $117.7 \pm 3.70$ & $125.81 \pm 5.33$ \\
\hline$*$ Significant at $p<0.05 . \quad * *$ Highly significant at $p<0.01$. & $* * *$ Very highly significant at $p<0.001$.
\end{tabular}


Table (2): The mean values of serum Glucose, Total protein, Albumin and Erythrocytes G-6-PD in control, cardiac infarction and olive leaves treated groups

\begin{tabular}{llccc}
\hline \multirow{2}{*}{ Test } & Groups & \multicolumn{3}{c}{ Periods } \\
& & $3^{\text {rd }}$ week & $6^{\text {th }}$ week & $9^{\text {th }}$ week \\
\hline \multirow{3}{*}{ Glucose } & Control (-ve) & $82.31 \pm 2.51$ & $89.51 \pm 2.31$ & $83.81 \pm 2.30$ \\
& ISO & $129.81 \pm 3.61^{*}$ & $159.87 \pm 5.11^{*}$ & $178.75 \pm 5.82^{*}$ \\
& Treated & $91.77 \pm 2.38$ & $119.81 \pm 3.75$ & $131.83 \pm 4.91^{*}$ \\
& Olive leaves Control (+ve) & $83.81 \pm 2.01$ & $95.18 \pm 3.11^{*}$ & $89.81 \pm 5.30$ \\
Erythrocytes & Control (-ve) & $7.01 \pm 0.39$ & $6.56 \pm 0.44$ & $6.89 \pm 0.38$ \\
G-6-PD & Treated & $10.12 \pm 1.51^{*}$ & $11.99 \pm 0.75^{*}$ & $14.75 \pm 1.01^{*}$ \\
& Olive leaves Control (+ve) & $8.15 \pm 0.38$ & $8.11 \pm 0.62$ & $8.75 \pm 0.54$ \\
Total & Control (-ve) & $6.25 \pm 0.73$ & $6.99 \pm 0.87$ & $6.98 \pm 0.89$ \\
protein & ISO & $5.98 \pm 0.75$ & $6.95 \pm 0.79$ & $7.11 \pm 0.58$ \\
& Treated & $6.87 \pm 0.70$ & $5.72 \pm 0.79$ & $5.28 \pm 0.67^{*}$ \\
& Olive leaves Control (+ve) & $6.99 \pm 0.88$ & $6.90 \pm 1.01$ & $6.93 \pm 0.93$ \\
Albumin & Control (-ve) & $4.23 \pm 0.52$ & $4.58 \pm 0.93$ & $8.49 \pm 0.97 *$ \\
& ISO & $4.29 \pm 0.79$ & $4.51 \pm 0.82$ & $4.51 \pm 0.51$ \\
& Treated & $4.19 \pm 0.31$ & $4.33 \pm 0.49$ & $3.85 \pm 0.78$ \\
& Olive leaves Control (+ve) & $5.11 \pm 0.72 *$ & $5.63 \pm 0.86^{*}$ & $4.44 \pm 0.81$ \\
\hline
\end{tabular}

* Significant at $p<0.05$. ** Highly significant at $p<0.01 . \quad * * *$ Very highly significant at $p<0.001$.

Table (3): The mean values of serum Calcium, Sodium, Potassium and Phosphorus in control, cardiac infarction and olive leaves treated groups

\begin{tabular}{clccc}
\hline \multirow{2}{*}{ Test } & \multicolumn{3}{c}{ Groups } & Periods \\
& & $3^{\text {rd }}$ week & $6^{\text {th }}$ week & $9^{\text {th }}$ week \\
\hline \multirow{4}{*}{ Calcium } & $8.71 \pm 0.38$ & $8.68 \pm 0.42$ & $8.79 \pm 0.51$ \\
& Control (-ve) & $7.05 \pm 0.61^{*}$ & $6.71 \pm 0.62^{*}$ & $6.15 \pm 1.02^{*}$ \\
& ISO & $8.01 \pm 0.36$ & $8.01 \pm 0.45$ & $8.90 \pm 0.62$ \\
& Treated & $8.26 \pm 0.39$ & $8.75 \pm 1.20$ & $8.51 \pm 1.13$ \\
& Olive leaves Control (+ve) & $151.53 \pm 3.11$ & $159.81 \pm 3.70$ & $161.82 \pm 4.11$ \\
& Control (-ve) & $101.35 \pm 4.75^{*}$ & $91.18 \pm 5.70^{* *}$ & $109.81 \pm 6.82^{* *}$ \\
& ISO & $139.82 \pm 3.75$ & $124.81 \pm 4.17$ & $128.11 \pm 3.35$ \\
Podium & $147.1 \pm 5.90$ & $159.75 \pm 4.75$ & $151.81 \pm 5.11$ \\
& Treated & $2.94 \pm 0.11$ & $2.98 \pm 0.21$ & $3.01 \pm 0.30$ \\
& Olive leaves Control (+ve) & $5.01 \pm 0.25^{*}$ & $5.93 \pm 0.51^{* *}$ & $6.59 \pm 0.78^{* *}$ \\
& Control (-ve) & $3.15 \pm 0.70$ & $4.01 \pm 0.53$ & $3.87 \pm 0.51$ \\
& ISO & $2.85 \pm 0.42$ & $2.88 \pm 0.78$ & $2.97 \pm 0.91$ \\
& Treated & $4.11 \pm 0.21$ & $4.22 \pm 0.17$ & $4.29 \pm 0.33$ \\
& Olive leaves Control (+ve) & $6.98 \pm 0.87^{*}$ & $8.79 \pm 1.11^{* *}$ & $8.88 \pm 1.21^{* *}$ \\
& Control (-ve) & $4.81 \pm 0.39$ & $4.91 \pm 0.81$ & $4.85 \pm 0.91$ \\
& ISO & $4.15 \pm 0.41$ & $3.99 \pm 1.01$ & $4.18 \pm 1.12$ \\
\hline
\end{tabular}

\section{DISSCUSSION}

Olive leaf has become extremely popular for its wide array of health benefits. Scientific studies have shown that olive leaf extract is valuable for maintaining cardiovascular health, joint health, fighting infections, boosting antioxidant status and supporting general wellbeing (El SNKarakaya 2009). ISO induces morphological and functional alterations in the heart leading to myocardial necrosis 
Table (4): The mean values of Cardiac tissues SOD, , CAT and L-MDA in control, cardiac infarction and olive leaves treated groups

\begin{tabular}{|c|c|c|c|c|}
\hline \multirow{2}{*}{ Test } & \multirow{2}{*}{ Groups } & \multicolumn{3}{|c|}{ Periods } \\
\hline & & $3^{\text {rd }}$ week & $6^{\text {th }}$ week & $9^{\text {th }}$ week \\
\hline \multirow{4}{*}{$\begin{array}{l}\text { Cardiac } \\
\text { tissues } \\
\text { SOD }\end{array}$} & Control (-ve) & $54.31 \pm 2.35$ & $50.75 \pm 3.11$ & $58.75 \pm 1.97$ \\
\hline & ISO & $30.75 \pm 2.22 *$ & $26.15 \pm 3.01 *$ & $20.10 \pm 1.98 *$ \\
\hline & Treated & $45.61 \pm 3.15$ & $41.31 \pm 2.77$ & $40.11 \pm 3.03$ \\
\hline & $\begin{array}{l}\text { Olive leaves Control } \\
(+v e)\end{array}$ & $52.63 \pm 2.54$ & $53.71 \pm 2.23$ & $51.91 \pm 2.01$ \\
\hline \multirow{4}{*}{$\begin{array}{l}\text { Cardiac } \\
\text { tissues } \\
\text { CAT }\end{array}$} & Control (-ve) & $61.75 \pm 4.44$ & $65.31 \pm 3.51$ & $59.88 \pm 3.16$ \\
\hline & ISO & $28.81 \pm 2.11 * *$ & $23.81 \pm 3.51 * *$ & $18.75 \pm 2.11^{* *}$ \\
\hline & Treated & $48.11 \pm 3.45$ & $54.27 \pm 3.75$ & $39.21 \pm 2.75$ \\
\hline & $\begin{array}{l}\text { Olive leaves Control } \\
(+\mathrm{ve})\end{array}$ & $60.15 \pm 3.33$ & $62.81 \pm 2.75$ & $57.26 \pm 3.01$ \\
\hline \multirow{4}{*}{$\begin{array}{l}\text { Cardiac } \\
\text { tissues } \\
\text { L-MDA }\end{array}$} & Control (-ve) & $0.77 \pm 0.03$ & $0.83 \pm 0.11$ & $0.89 \pm 0.12$ \\
\hline & ISO & $2.85 \pm 0.13^{* *}$ & $3.11 \pm 0.25^{* *}$ & $4.54 \pm 0.39 * *$ \\
\hline & Treated & $0.88 \pm 0.05$ & $0.79 \pm 0.03$ & $0.91 \pm 0.12$ \\
\hline & $\begin{array}{l}\text { Olive leaves Control } \\
(+\mathrm{ve})\end{array}$ & $0.78 \pm 0.36$ & $0.85 \pm 0.31$ & $0.97 \pm 0.35$ \\
\hline
\end{tabular}

showed as membrane permeability alterations, led to loss of function and integrity of myocardial membrane, and the crucial role of free radicals in pathogenesis of ISO induced myocardial damage. The path - physiological changes following ISO administration are comparable to those taking place in human myocardial alterations (Karthikeyan et al., 2007)

The significant increases in serum CK, CK$\mathrm{MB}, \mathrm{LDH}$ in treated or olive leaves group after olive leaves administration to rat. This increase is much less than the ISO group. The obtained results are in agreement with those reported by (Covas et al., 2006a). This decrease than ISO group suggestes that olive leaves had cardio-protective compounds hence, cardiac markers showed lower levels than ISO group strongly indicate cardiac protection of olive leaves and prevention against damage to cardiac muscle (Manna et al., 2004). The recorded highly significant increases in the activity of serum AST activity in ISO group. These Data agree with those reported by (Moreno 2003) who found that, the enzyme activity AST in serum of rats decreased significantly when they were fed on a diet containing olive leaves. Also, olive leaves stabilized cell membrane and protected the liver against deleterious agents and free radical-mediated toxic damages to the liver cells and this is reflected in the reduction of liver enzyme. Olive oil and leaves help the liver to maintain its normal function by accelerating the regenerative capacity of its cells (Ruano et al., 2007). These results are also in agreement with (Sharmila and Rajadurai, 2012) who recorded significant increase in $\mathrm{CK}, \mathrm{CK}-\mathrm{MB}, \mathrm{LDH}$ and AST activities and reported that, the increase may be due to the damage caused by ISO, the cardio toxic agent to the myocardial cells (Lalitha et al., 2012). The activity of CK-MB is the most diagnostic for MI because of the marked abundance of this isoenzyme in myocardium and virtual absence from most other tissues and its consequent sensitivity (detection of necrosis of less than $100 \mathrm{mg}$ of myocardium). The magnitude and persistence of elevation are useful in estimating the extent of infarction (Sobel, 1992). Heart damage induced by ISO was indicated by elevated levels of the marker enzyme such as CK-MB in serum as reported by (Ahmed et al., 2004). The recorded significant increase in serum 
glucose in ISO group when compared to the control group and that may be due to the enhanced glycogen breakdown and less utilization of peripheral tissues (Mijnhout et al., 2010). Furthermore, in isoproterenol induced myocardial infracted rats, blood glucose level was found to be increased, whereas heart tissue glycogen level was found to be decreased when compared to control animals (Rajendranand Basha, 2008). In this respect Zakirov et al. (2000) have reported the decreased level of glycogen in isoproternol induced myocardial infracted rats, due to Isoproterenol administration followed by beta receptor binding activates phosphorylase kinase leading to glycogenolysis (Aghi et al., 1992). Administration of olive leaves before and after isoproterenol injection (treated group showed a general significant decrease than the ISO group in serum glucose and that may be due to the antioxidative property of olive leaves which can normalize the oxidative stress produced by ISO (Al-Reza et al., 2009). The recorded changes in Erythrocytes G6PD in the treated when compared to the control group after olive leaves administration to normal rat and that might be because olive leaves depressed the activities of lipogenic and cholesterogenic enzymes such as Malic enzyme, fatty acid synthase, glucose 6 phosphate dehydrogenase and 3- hydroxy-3- methylglutryl CoA reductase (Fki et al., 2005). The significant increase in serum $\mathrm{K}$ and $\mathrm{P}$ and significant decrease in serum $\mathrm{Ca}$ and $\mathrm{Na}$ in ISO group while in the treated group no significant increase in serum $\mathrm{K}$ and $\mathrm{P}$ and no significant decrease in serum $\mathrm{Ca}$ and $\mathrm{Na}$. The results are similar to (Poudyal et al., 2010) who stated that the absorbed dietary calcium is usually filtered in the kidney (98$99 \%$ ) and reabsorbed from renal tubules into the blood; it appear that its decrease in serum probably resulted from either poor intestinal absorption or decreased renal reabsorption. Another possible mechanism for this observation could be a humeral effect of olive leaves on the calcium metabolic hormones such as parathormone, 1, 25-dihydroxy cholecalciferol and calcitonin. These remain a subject for further investigation. The marked decrease in serum sodium concentration observed by (Scheffler et al., 2008) who attributed that to a change in glomerular filtration rate and /or renal blood flow or interference with aldosterone secretion and /or action on the distal tubules or interference with adrenergic sodium handling. The non significant slightly increased $\mathrm{K}$ level in the treated group which is lower than the ISO group suggested a mild hypokalaemic effects and that may be due to an improvement in renal function by increasing potassium reabsorption. Additionally, another reason for olive leaves to increase serum levels of potassium and phosphorus non significantly in comparison to the control group may be beacuse that olive leaves increase mineral absorption (Najafizadeh et al., 2013). Furthermore, ( Diaz-Muñoz, et al 2006) have stated that the damage caused by ISO is probably due to action on the sarcolemmal membrane, stimulation of adenylate cyclase, activation of $\mathrm{Na}^{+}$and $\mathrm{Ca}^{++}$channels, exaggerated $\mathrm{Ca}$ inflow and energy consumption leading to cellular death. The recorded changes in cardiac tissue SOD and CAT in ISO group when compared to control rats and that may be due to Isoproterenol produce quinones which react with oxygen to generate superoxide anions $\left(\mathrm{O}_{2}^{--}\right)$and $\mathrm{H}_{2} \mathrm{O}_{2}$, which have damaging effects in cells (Rathore et al., 2000). Superoxide radicals generated at the site of damage in MI modulates SOD and catalase resulting in the lowered activities of these enzymes and accumulation of superoxide anion, which also damages the myocardium (Saravanan and Prakash, 2004). Isoproterenol induced MI leads to the gradual loss of endogenous oxidant/antioxidant balance. The endogenous defense network constitutes enzymatic and non-enzymatic antioxidants (Dhalla et al., 2000). Decrease in the values of SOD and CAT following isoproterenol 
administration indicate overwhelming of free radicals, which ensures oxidative damage to the myocardium (Ojha et al., 2013). Administration of olive leaves pre and post ISO injection in protective and treated groups showed significant increase in tissue SOD and CAT when compared to ISO group and that may be due to olive oil and leaves increased the activity of SOD and CAT and it scavenges superoxide radicals so reduces the myocardial damage caused by free radicals (Ruano et al., 2005). The showed decrease in tissue MDA (one of the end products of lipid peroxidation processes) after olive leaves administration in the treated group in comparison to the ISO group. The results are in agreement with Visioli et al. (2000b) who reported that olive oil and leaves have antioxidant properties, which could have inhibited lipoxygenase enzymes, and increases the antioxidant capacity. The results are in agreement with the data of Wang et al. (2008) who stated that olive oil and leaves decreased the MDA level by preventing formation of lipid peroxides from fatty acids and that inhibition of lipid peroxidase may be due to the antioxidant property of olive oil and leaves. ISO induced myocardial infarction is a free radical mediated tissue damage and may lead to the production of more oxygen and hydrogen peroxide ions which in turn bind with albumin and destroy it (Dhalla, et al 2010). A decrease in albumin with a rise in the alpha 2 globulin usually indicates an acute reaction of the type that occurs in infections, burns, stress or heart attack (Jacobs, 1996). Cornwell and Ma (2008) demonstrated that significant increase in serum total proteins and albumin was observed in olive leaves administrated rats, that indicates its ability to stimulate the regeneration of hepatic tissue which increase protein synthesis in damaged liver and improvement of the functional status of the liver cells. It has antioxidant effects; it can reduce toxicity associated free radical damage and play a role in improving host immunity and normalizing the oxygen utilization in cells.
In addition, it has been found to inhibit lipid peroxidation which is considered one of the main features of aging in liver cells (Corona et al., 2006). The increase in total serum protein level indicate the ability of olive oil and leaves to stimulate the regeneration of hepatic tissue which increase protein synthesis in damaged liver and improve the functional and status of the liver cells (Micol et al., 2005). Administration of olive leaves reverted back these changes to near normal it may be due to the decreased state of protein catabolism and induced a direct positive effect on the synthesis and secretion of albumin (Szende et al., 1994).

\section{CONCLUSION}

The findings of the present study demonstrated that Olive leaves administration is effective against myocardial infarction and oxidative damage in heart tissue. Also, we strongly support that, the use of olive leaves as a pure active ingredient in pharmacological industry for production of new drugs used as therapeutics for treatment and protection from heart diseases.

\section{REFERENCES}

Aghi, M.; Husiain, Z.; Pillar, K.K.; Quadry, J.S.; Balani, D.K. and Imran, M. 1992. Cardioprotective of cromokalim in isoproterenol induced myocardial infarction in rats. Ind. J. Exp. Biol., 30(7):611614.

Ahmed, K.K.; Rana, A.C. and Dixit, V.K. 2004. Effect of calotropis pocera latex on isoproterenol induced myocardial infarction in albino rats. Phytomedicine, 11:327-30.

Alonso, A.; Ruiz-Gutierrez, V. and Martínez-González, M.A. 2006. Monounsaturated fatty acids, olive oil and blood pressure: epidemiological, clinical and experimental evidence. Public Health Nutr.; 9: 251-257. 
Al-Reza, S.M.; Bajpai, V.K. and Kang, S.C. 2009. Antioxidant and antilisterial effect of seed essential oil and organic extracts from Zizyphus jujuba. Food Chem. Toxicol., 47: 2374-2380.

Bauer, J.D. 1982. 33. Clinic laboratory methods. 9th Ed: 555, the C.V. company, Westline Industrial Missouri.

Berry, M.N.; Mazzachi, R.D. and Rajakovic, M. 1989. Enzymatic determination of potassium in serum. Clin. Chem., 35:817-20.

Cornwell, D.G. and Ma, J. 2008. Nutritional benefit of olive oil: the biological effects of hydroxytyrosol and its arylating quinone adducts. J. Agric. Food Chem., 56:8774-8786.

Corona, G.; Tzounis, X.; Assunta Dessi, M.; Deiana, M.; Debnam, E.S.; Visioli, F.; et al. 2006. The fate of olive oil polyphenols in the gastrointestinal tract: implications of gastric and colonic microfloradependent biotransformation. Free Rad Res., 40:647-705.

Covas, M.I.; de la Torre, K.; FarréAlbaladejo, M.; Kaikkonen, J.; Fitó, M.; López-Sabater, C.; et al. 2006a. Postprandial LDL phenolic content and LDL oxidation is modulated by olive oil phenolic compound in human. Free Rad. Biol. Med., 40: 608-624.

Dhalla, N.S.; Elmoselhi, A.B.; Hata, T. and Makino, N. 2000. Status of myocardial antioxidants in ischemia- reperfusion injury. Cardiovas Res., 47:446-456.

Dhalla, N.S.; Temsh, R.M.; Netticadan, T. 2010. Role of oxidative stress in cardiovascular diseases. J. Hypertension, 18:655-673.

Diaz-Muñoz, M.; Älvarez-Perez, M.A.; Yañez, L.; Vidrio, S.; Martinez, L.; Rasas, G.; Yañez, M.; Ramirez, S. and Chagoya de Sánchez, V. 2006. Correlation between oxidative stress and alteration of intercellular calcium haandling in isoproterenolinduced myocardial infarction. Mol. Cell Biochem., 289: 125-136.

Douma, B.T.; Watson, W.A. and Biggs, H.G. 1971. Albumin standards and the measurement of serum albumin with bromocresol green. Clin. Acta, 31: 87-96.

El, S.N. and Karakaya, S. 2009. Olive tree (Olea europaea) leaves: potential beneficial effects on human health. Nutr. Rev., 67:632-638.

Elizabeth, G.; Nabel and Eugene, B. (2012). N. Engl. J. Med. 366: 54-63.

Fki, I.; Bouaziz, M.; Sahnoun, Z. and Sayadi, S. 2005. Hypocholesterolemic effects of phenolicrich extracts of Chemlali olive cultivar in rats fed a cholesterol rich diet. Bioorg. Med. Chem., 13: 53625432.

Gamst, O. and Try, K. 1980. Determination of serum-phosphate without deproteinization by ultraviolet spectrophotometry of the phosphomolybdic acid complex. Scand J. Clin. Lab. Invest., 40(5): 483.

Karthikeyan, K.; Bai, B.R.S. and Deveraj, S.N. 2007. Cardioprotective effect of grape Seed Proanthocyanidins on isoproterenol Induced myocardial injury in rats. Int. J. Cardiol., 115: 326-333.

Lalitha, G.; Poornima, P.; Archanach, A. and Padma, V. 2012. Protective effect of neferine against isoproterenol induced cardiac toxicity. Springer Science, 13: 168179.

Manna, C.; Migliardi, V.; Golino, P.; Scognamiglio, A.; Galletti, P.; Chiariello, M. and Zappia, V. 2004. Oleuropein prevents oxidative myocardial injury induced by ischemia and reperfusion. J. Nutr. Biochem., 15: 461-466.

McLean, F.C. andHastings, A.B. 1935. Thestate of calcium in the fluids of the bodyThe conditions affecting 
theionization of calcium. J. Biol. Chem., 108: 285-322

Micol, V.; Caturla, N.; Perez-Fons, L.; Estepa, A.; Mas, V. and Perez, L. 2005. The olive leaf extract exhibits antiviral activity against viral haemorrhagic septicaemia rhabdovirus (VHSV). Antiviral Res.; 66: 129-136.

Mijnhut, G.; Alkhalaf, A.; Kleefstra, N. and Bilo, H. 2010. Alpha lipoic acid. a new treatment for newrophathic pain in patients with dibetes. Netherland J. Med., 68(4):158-162.

Moreno, J.J. 2003. Effect of olive oil minor components on oxidative stress and arachidonic acid mobilization and metabolism by macrophages RAW 264.7. Free Rad. Biol. Med., 35: 1073-1081.

Mudagal, M.; Karia, S. and Goli, D. 2011. Preventive effect of rhododendron arboretum on cardiac markers. Lioid peroxides and antioxants in normal and isoproterenol induced myocardial necrosis in rats. African J. Pharmacology; 5(6):755-763.

Najafizadeh, P.; Dehghani, F.; Panjeh, S.M. and Hamzei, T.S. 2013. The effect of a hydro-alcoholic extract of olive fruit on reproductive argons in male sprague-dawley rat. Iran J. Reprod Med., 11(4):293-300.

Nishikmi, M.; Appaji, N. and Yagi, K. (1972). The occurrence of superoxide anion in the reaction of reduced phanazine methosulfate and molecular oxygen. Biochem. Biophys Res. Commun, 4(2):84954.

Ohkawa, H.; Onishi, N. and Yagik 1979. Assay for lipid peroxides in animal tissue by thiobabituric acid reaction. Anal. Biochem., 95:351-8.

Ojha, S.; Goyal, S.; Sharma, C.; Arora, S.; Kumari, S. and Arya, D. 2013. cardioprotective effect of lycopene against isoproterenol-induced myocardial infarction in rats.
Human and Experimental Toxicity., 32(5): 492-503.

Patel Upaganlawar, A.; Zalawadia, R.; and

Balaraman, R. 2010. Cardioprotective effect of melatonin against isoproterenol induced myocardial infarction in rats: abiochemical, electro cardiographic and histoarchitectural evaluation European J. Pharmacology, 644: 160-168.

Poudyl, H.; Campbell, F. and Brown, L. (2010). Olive leaf extract attenuates cardiac, hepatic, and metabolic changes in high carbohydrate-, high fat-fed rats. J. Nutr., 140: 946-953.

Rathore, N.; Kale, M.; John, S. and Bhatnagar, D. 2000. Lipid peroxidation and antioxidant enzymes in isoproterenol induced oxidative stress in rat erythrocytes. Ind J. Physiol. Pharmacol., 44: 161166.

Reitman, S. and Frankel, S. 1957. Acolorimetric method for the determination of serum glutamate oxaloacetic and glutamate Pyruvic transaminases. Amerrican J. Clinical Pathology, 28(1):56-63.

Ruano, J.; López-Miranda, J.; Fuentes, F.; Moreno, A.; Bellido, C.; PérezMartínez, P.; et al. 2005. Phenolic content of virgin olive oil improves ischemic reactive hyperemia in hypercholesterolemic patients. J. Am. Coll. Cardiol., 46:1864-1872.

Ruano, J.; Lopez-Miranda, J.; DelgadoLista, J.; Fernandez, J.; Caballero, J.; Covas, M.I.; Jimenez, Y.; PerezMartinez, P.; Marin, C.; Fuentes, F. and Perez-Jemenez, F. 2007. Intake of phenol-rich virgin olive oil improves the postprandial prothrombotic profile in hypercholesterolemic patients. Am. J. Clin. Nutr., 86:341-346.

Saravanan, G. and Prakash, J. 2004. Effect of garlic (Allium sativum) on Lipid peroxidation in experimental 
myocardial infarction in rats. $\mathrm{J}$. Ethnopharm., 94:155-158.

Scheffler, A.; Rauwald, H.W.; Kampa, B.; Mann, U.; Mohr, F.W. and Dhein, S. 2008. Olea europaea leaf extract exerts Ltype $\mathrm{Ca} 2+$ channel antagonistic effects. J. Ethnopharmacol.; 120: 233-240.

Scientific Committee 1982. Recommandations pour la measure de 1 concentration catlyique de lactate deshidrogemasedans le serum humana 300c. Ann. Biol. Clin., 40:87-164.

Sharmila, S. and Rajadurai, M. 2012. Preventive effect of BIO-AQ on cardiac markers, Lipids, and membrane bound enzymes in isooproternol induced myocardial infarction in rats. Asian J. Pharma. and Clinical Res.; 5(2):107-113.

Sinha, A.K. 1972. Colorimetric assay of catalase. Anal. Biochem., 47: 389394.

Sobel, B.E. 1992. Acute myocardial infarction. In Wyngarden, J.B. Smith, L.H. Jr, Bennett, J.C. (eds). Cecil Textbook of medicine, $19^{\text {th }}$ edn. W.B. Saunders, Co.; Philadelphia, PA, 304-18.

Szende, B.; Timár, F. and Hargitai, B. (1994). Olive oil decreases liver damage in rats caused by carbon tetrachloride $\left(\mathrm{CCl}_{4}\right)$. Exp.Toxicol. Pathol., 46: 355-359.

Tinkel, J.; Hassanain, H. and Khouri, S.J. 2012. Cardiovascular antioxidant thaerapy: areview of supplements, phamacotherapies and mechanisms. Cardiol Rev., 20: 77-83.

Trinder, P. 1969. Determination of glucose in blood using glucose oxidase with an alternative oxygen acceptor. Ann. Clin. Biochem. 6: 24-32.

Urdal, P. and Landaa, S. 1979. Clin. Chem. 25: 461-465.
Visioli, F.; Bellomo, G.; Montedoro, G. and Galli, C. 1995. Low density lipoprotein oxidation is inhibited in vitro by olive oil constituents. Atherosclerosis, 117: 25-32.

Visioli, F.; Galli, C.; Bornet, F.; Mattei, A.; Patelli, R.; Galli, G.; et al. 2002. Olive oil phenolics are dosedependently absorbed in humans. FEBS Lett., 468:159-219.

Visioli, F.; Galli, C.; Plasmati, E.; et al. 2000b. Olive oil phenol hydroytyrosol prevents passive smoking-induced oxidative stress. Circulation, 102:2169-240.

Visioli, F.; Poli, A. and Galli, C. 2002. Antioxidant and other biological activities of phenols from olives and olive oil. Med. Res. Rev., 22:65-75.

Wang, L.; Geng, C.; Jiang, L.; Gong, G.; Liu, D.; Yoshimurah and Zhong, L. 2008. The anti-atherosclerotic effect of olive leaf extract is related to suppressed inflammatory response in rabbits with experimental atherosclerosis. Eur. J. Nutr., 47: 235-243.

Wang, S.B.; Tian, S.; Yang, F.; Yang, H.G.; Yang, X.Y. and Du, G.H. 2009. Cardioprotective effect of salvianolic acid A on isoproterenolinduced myocardial infarction in rats. Eur. J. Pharmacol., 615:125132.

Young, C.E.; Karas, R.H. and Kuvin, J.T. 2004. High-density lipoprotein cholesterol and coronary heart disease. Cardiol. Rev., 12: 107-119.

Zakirov, N.V.; Aizikov, M.I. and Kurmukov, A.G. 2000. cardio protective effect of glycyram in myocardial damage induced by isadrin. EKSP. Klin. Framakol., 63(5):24-6. 